DOI

\title{
СОЦІАЛЬНО-ЕКОНОМІЧНА ТА КУЛЬТУРНО-ОСВІТНЯ ХАРАКТЕРИСТИКА СТУДЕНТІВ-ІНОЗЕМЦІВ ВИЩОГО МЕДИЧНОГО НАВЧАЛЬНОГО ЗАКЛАДУ
}

\author{
I. М. Карпінець \\ ДВНЗ “Івано-Франківський національний медичний університет”

\section{SOCIO-ECONOMIC, CULTURAL AND EDUCATIONAL CHARACTERISTICS OF FOREIGN STUDENTS IN HIGHER MEDICAL EDUCATIONAL INSTITUTIONS}

\section{M. Karpinets}

\author{
SHEI "Ivano-Frankivsk National Medical University"
}

\begin{abstract}
Проведене дослідження присвячене вивченню деяких соціально-економічних характеристик 166 студентів 315 країн світу, які навчаються на п’ятому курсі за спеціальністю “Лікувальна справа” в ДВНЗ “Івано-Франківський національний медичний університет”.
\end{abstract}

The research is devoted to the study of some social and economic characteristics of 166 students from 15 countries. They are fifth-year students of the specialty “General medicine” studying at Ivano-Frankivsk National Medical University.

Вступ. На сьогодні в Україні навчаються студенти з 134 країн світу (США, Китай, Туркменистан, Індія, Росія, Ірак тощо), загальна чисельність становить близько 50 тисяч. Згідно з даними Міністерства освіти і науки України, щорічний приріст іноземних студентів становить 10 \%, при цьому наша країна посідає дев'яте місце у світі за кількістю студентів-іноземців [1-3].

Навчання іноземних громадян у ДВНЗ “ІваноФранківський національний медичний університет” (ІФНМУ) проводиться з 1992 року. Нині цей заклад входить у шестірку кращих вищих медичних навчальних закладів України, що очевидно приваблює іноземців як за якістю освіти, так і вартістю навчання. Зокрема, дипломи ІФНМУ визнаються у Йорданії, Палестинській автономії та інших країнах Близького Сходу. На часі - визнання університету у Королівстві Малайзія [4]. В інших країнах абсолютна більшість випускників нострифікує дипломи згідно з національними освітніми вимогами.

На даний момент (2015 рік) в ІФНМУ налічується понад 1460 іноземних студентів, які приїхали на навчання більше як 345 країн світу.

(C) I. М. Карпінець
Основна частина. За розробленою програмою опитано 166 студентів з 15 країн світу, які навчаються на п’ятому курсі за спеціальністю “Лікувальна справа” в ІФНМУ, яких було поділено за регіонами походження студентів: Африканський континент - 77 студентів, Південна Азія - 42, Близький Схід - 40 та Європа - 7 студентів.

Встановлено, що серед опитаних студентів переважають особи чоловічої статі (66,3%) проти (33,7\%) жінок, $\mathrm{p}<0,001$. Звертають на себе увагу особливості статевої структури респондентів залежно від континенту походження (рис. 1). Так, якщо зазначений розподіл студентів з Африканського та Азійського континентів був приблизно однаковим (58,4 \% чоловіків і 41,6 \% жінок та 54,8 \% і 45,2 \% відповідно), то в статевій структурі уродженців Близького Сходу суттєво переважали чоловіки $(90,0$ \% і 10,0 \%). Крім того, абсолютна більшість студентів була містянами (88,0 \%). Очевидно, такий розподіл пов'язаний із пересторогами сімей студентів, зокрема щодо дівчат, та особливостями східного менталітету, культури, релігії тощо.

Результати дослідження показали, що віросповідання студентів-іноземців прогнозовано залежить від країни проживання, $\mathrm{p}<0,001$ (рис. 2). Зокре- 


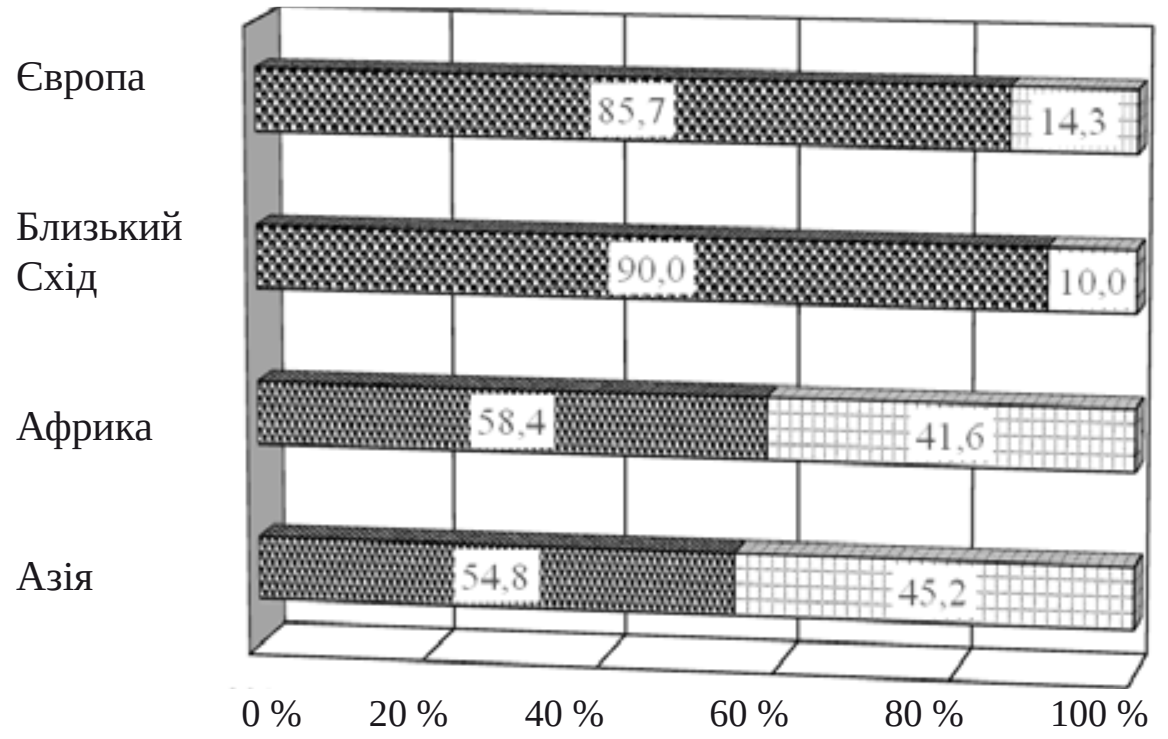

Рис. 1. Статева структура студентів залежно від континенту походження, \%.

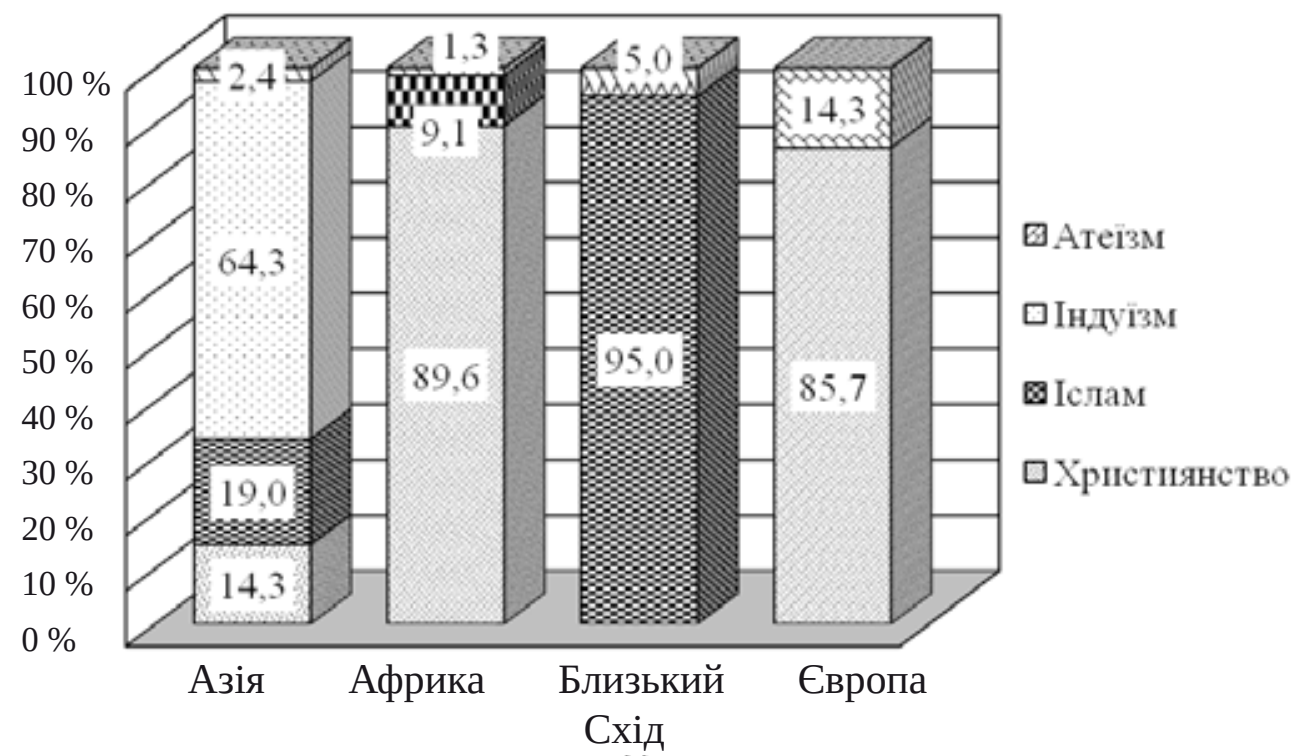

Рис. 2. Розподіл студентів за віросповіданням залежно від континенту походження, \%.

ма, левова частка респондентів країн Європи та Африканського континентів сповідує християнство (85,7 \% і 89,6 \%), дві третини вихідців Південної Азії - індуїзм (64,3 \%), абсолютна більшість студентів-арабів - іслам (95,0%). Зрозуміло, що таке різноманіття релігійних уподобань вимагає досить тривалого періоду адаптації іноземних громадян як у середині студентської громади, так і в соціумі загалом.

Слід зауважити, що респонденти походили 3 досить високоосвічених родин - 73,5 \% тат та 61,4 \% матерів мали закінчену вищу освіту. Проте вражає, що практично десята частина $(8,4$ \%) бать- ків є взагалі неписьменними або мають тільки початкову освіту. При цьому неписьменні матері опитаних студентів були тільки з країн Південної Азії (2,4 \%) та Близького Сходу (2,5 \%).

Встановлено, що багатодітність характерна для сімей студентів-іноземців, вихідців 3 країн Близького Сходу та Африканського континенту - близько трьох братів/сестер на кожного респондента.

Результати інтерв’ю засвідчили, що рівень матеріального благополуччя опитаних студентів досить різноманітний-приблизно половина з них (48,2%) оцінила свої фінансові статки як такі, що дають можливість достойно та комфортно проживати у своїй 
країні, ще 45,2 \% - як середні, і тільки 6,6 \% вважають себе бідними. Аналізуючи розподіл у середині порівнюваних груп, встановлено, що найбільш бідними себе вважали студенти з країн Південної Азії14,3 \% проти 3,9 \% уродженців африканців та 2,5 \% арабів $(\mathrm{p}<0,01)$. Звичайно, що така суб’ єктивна оцінка значною мірою обумовлена загальним рівнем добробуту країни проживання.

На тлі сказаного зрозуміло, чому основною мотивацією обрання України для отримання вищої медичної освіти стала відносна дешевизна навчання (42,8 \%), причому цей показник сформувався, в основному, за рахунок студентів - вихідців із країн Середньої Азії (59,5 \%) та Африканського континенту (44,2 \%), p<0,01. Решта причин була менш вагомою: привабливість закордонного навчання взагалі (32,5 \%), неможливість вступити до вищого навчального закладу своєї країни (19,9 \%, зокрема 40,0 \% арабів та 42,9 \% європейців, р<0,01) та інші поодинокі мотиви (досвід навчання батьків в Україні, поради знайомих та друзів, якісна освіта, відсутність візових проблем та страйків в університетах).
Звертає на себе увагу досить високий рівень шкільної підготовки опитаних студентів-іноземців, незалежно від країни походження. Зокрема, половина респондентів (50,6 \%) закінчила школу 3 добрими оцінками (переважно В за рейтинговою шкалою ECTS) і третина (29,5 \%) отримала відмінний атестат (А відповідно). Звичайно, це неабиякий позитивний фундамент на шляху здобуття університетської освіти.

Сказане підтверджується і рівнем володіння іноземною мовою серед опитаних студентів. Незважаючи на різноманіття країн походження, абсолютна більшість (80,1 \%) добре володіє обраною мовою навчання в Україні.

Встановлено, що практично всі (87,3 \%) опитані студенти-іноземці, незалежно від континенту проживання, мали перед собою чітко окреслену мету стати лікарем (рис. 3). Однак не може не насторожити, що десята частина респондентів стала студентами медичного університету практично “випадково” - 7,8 \% за переконанням батьків і ще для 4,2% вибір майбутньої професії був не принциповим.

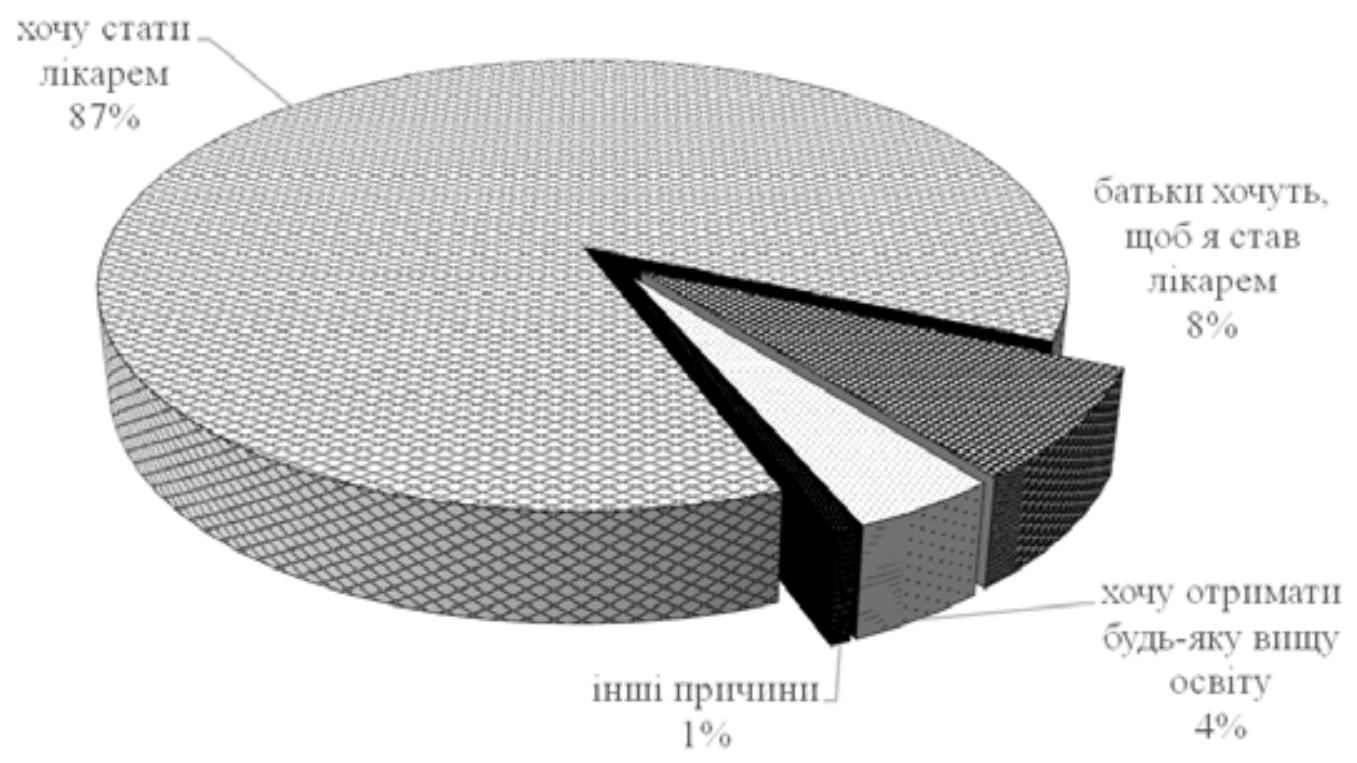

Рис. 3. Розподіл студентів за причинами навчання в Україні, \%.

У світлі сказаного не дивно, що кожен десятий опитаний студент-іноземець сумнівається в правильності вибраної спеціальності (9,0%), більшість 3 яких (77,5 \%) - араби.

Висновок. Встановлено, що серед студентівіноземців ІФНМУ переважають особи чоловічої статі (66,3 \%), міські жителі (88,0 \%), із достатньо високим базовим рівнем середньої освіти (80,1%) і володіння обраною мовою навчання (80,1%). Показано, що залежно від континенту походження респонденти відрізняються за віросповіданням, рівнем добробуту, складом сімей та рівнем освіти батьків, що очевидно має вплив на мотиви вибору України для отримання вищої медичної освіти. Виявлене суттєве різноманіття соціально-економічних та культурно-освітніх відмінностей іноземних студентів слід враховувати при формуванні груп навчання та при організації навчальної, виховної роботи і дозвілля студентів. 


\section{Список літератури}

1. Офіційний сайт Міністерства освіти і науки України [Електронний ресурс]. - Режим доступу : http:// www.mon.gov.ua/index.php/ua/arkhiv/2010?view=archiv e\&month $=5$.

2. Довгодько Т. І. Розвиток системи підготовки іноземних студентів в Україні / Т. І. Довгодько // Вища освіта України. - 2012. - Т. 2, № 3 (дод. 2). - С. 102 - 104.

3. Іщенко О. Інтернаціоналізація студентського освітнього середовища: особливості протікання процесу в
Україні / О. Іщенко // Вісник НТУУ “КПІ”. - 2010. № 2. - С. 18 - 23.

4. Офіційний сайт ДВНЗ “Івано-Франківський національний медичний університет” [Електронний ресурс]. Режим доступу : http://www.ifnmu.edu.ua/uk/2011-11-1012-10-02/item/3828.

5. Децик О. 3. Методичні підходи до узагальнення результатів наукових досліджень / О. 3. Децик // Галицький лікарський вісник. - 2011. - Т. 18, № 2. - С. 5-8.

Отримано 28.10.15 